\title{
Retrieval of lost patients in the system for hepatitis $C$ microelimination: a single-center retrospective study
}

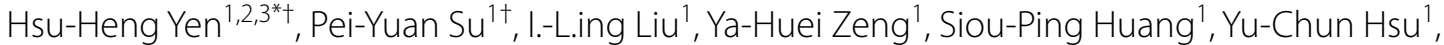 \\ Po-Ke Hsu ${ }^{1}$ and Yang-Yuan Chen ${ }^{1,4^{*}}$
}

\begin{abstract}
Background: Hepatitis C virus (HCV) is one of the major causes of chronic liver disease, cirrhosis, and liver cancer. Most of the infected people have no clinical symptoms. The current strategy for HCV elimination includes test and treatment. In this study, we aimed to evaluate the campaign for retrieving patients who were lost to follow-up, for subsequent re-evaluation.
\end{abstract}

Methods: From January 2020 to October 2020, patients who had prior tests for positive anti-HCV antibody in 20102018 in our hospital were enrolled for our patient callback campaign. Patients who had unknown HCV RNA status or no documented successful antiviral therapy history were selected for anti-HCV therapy re-evaluation. To facilitate patient referral in the hospital, we developed an electronic reminding system and called the candidate patients via telephone during the study period.

Results: Through the hospital electronic system, 3783 patients with positive anti-HCV antibody documentation were identified. Among them, 1446 (38.22\%) had tested negative for HCV RNA or had anti-HCV therapy, thereby excluded. Of the 2337 eligible patients, 1472 (62.99\%) were successfully contacted and called back during the study period for subsequent HCV RNA testing and therapy. We found that $42.19 \%$ of the patients had positive HCV RNA and $88 \%$ received subsequent anti-HCV therapy.

Conclusions: A significant number of patients with positive HCV serology were lost for HCV confirmatory test or therapy in the hospital. Therefore, this targeted HCV callback approach in the hospital is feasible and effective in achieving microelimination.

\section{Introduction}

Chronic hepatitis $\mathrm{C}(\mathrm{CHC})$ is a major cause of chronic liver disease and liver cancer worldwide. Currently, with the newly developed direct-acting antiviral agents (DAAs), treatment of hepatitis $\mathrm{C}$ virus (HCV) infection

\footnotetext{
*Correspondence: 91646@cch.org.tw; blaneyen@gmail.com; 27716@cch.org. tw; ychen02@gmail.com

${ }^{\dagger} \mathrm{H}$ su-Heng Yen and Pei-Yuan Su have contributed equally to this work

${ }^{1}$ Division of Gastroenterology, Department of Internal Medicine,

Changhua Christian Hospital, No. 135 Nanhsiao Street, Changhua, Taiwan

Full list of author information is available at the end of the article
}

has revolutionized compared with that during the interferon-based era, with significantly high rates of sustained virologic response (SVR) (>90\%) and good treatment tolerance even in those groups that are difficult to treat [14]. Through screening for early diagnosis and reducing the barriers for $\mathrm{HCV}$ treatment, the prevalence of $\mathrm{HCV}$ induced chronic liver diseases and HCV-related mortality will be mitigated. The screening and diagnosis of $\mathrm{HCV}$ infection and patients' adherence to treatment involve several barriers, including cost, patient awareness, and in adequate manpower. The microelimination approach $[5$, 
6] in specific populations is less complex and less costly than the nationwide elimination approach. Specific highrisk populations such as injection drug users [7], prisoners [8], HIV-infected patients [2, 9], and dialysis patients [3] have been screened as the first step toward HCV elimination.

One target population for $\mathrm{HCV}$ elimination is those patients with records of hepatitis $\mathrm{C}$ antibody testing in the hospital. Testing for hepatitis $\mathrm{C}$ can be performed for several reasons, such as survey for abnormal liver function, preoperative checkup, blood donation, before chemotherapy, or routine physical checkup.

Despite that HCV antibody-positive patients clearly need HCV testing or treatment, Fujii [10] reported the lack of intrahospital collaboration even in medical institutions with hepatologists. Only $12 \%$ of probable HCVpositive patients were referred to specialists [11], and the majority were lost to follow-up; thus, they did not receive the subsequent therapy. Given that these new DAAs have been reimbursed by Taiwan health system since 2017 and the government set a goal of $80 \%$ treatment coverage rate with DAAs by 2025 in Taiwan [12], our hospital organized the "Retrieval of Lost Patients of the Hospital" strategy in 2020, aimed to eliminate HCV infection in the hospital by searching first for patients with a history of HCV infection who were lost to follow-up. Thus, the current study aimed to evaluate the outcome of this hospital-based HCV elimination approach for patients who were lost to follow-up.

\section{Materials and methods}

In 2020, the Health Promotion Administration of Ministry of Health and Welfare in Taiwan initiated a hepatitis $\mathrm{C}$ testing and treatment program that aims to eliminate $\mathrm{HCV}$ infection nationwide. As the only medical center in Changhua County, with an area of $1074 \mathrm{~km}^{2}$ and a population of 1.2 million located in central Taiwan, our hospital organized a hospital-based project called "Retrieval of Lost Patients of the Hospital" in response to the hepatitis $\mathrm{C}$ elimination campaign established by the Taiwan government in 2020.

Two dedicated nurses (Liu IL and Zang YH) recontacted patients who were eligible for re-evaluation and one senior hepatologist (Su PY) reviewed the patients' records to evaluate the recent status of patients' survival and comorbidity status. Furthermore, using PharmaCloud in Taiwan [13], we could assess the pharmacy record of patients in the last 3 months to determine if they had been treated in other hospitals. Subsequent strategies included posting reminding sticks or electronic messages during clinic visits to facilitate referring patients to our hepatologist for subsequent evaluation and contacting the patients via telephone, SMS, or mails as possible. For HCV RNA testing and patient referral, this callback campaign adopted an HCV reflex test [14] approach with simultaneous HCV RNA and genotype checkup.

Patients who tested positive for hepatitis $\mathrm{C}$ antibody in the hospital between 2010 and 2018 were included for the analysis. Under the approval by Changhua Christian Hospital Institutional Review Board (CCH IRB No. 200403) with the consideration of the retrospective design of the study, informed consent was waived. From the electronic medical records, medical information regarding patients' demographics, comorbid conditions, anti-HCV treatment history, and laboratory values for HCV RNA status was extracted. All procedures conformed to the guidelines and regulations of Changhua Christian Hospital.

\section{Statistical analysis}

Data are expressed as $\mathrm{n} / \mathrm{N}$ (\%), median (interquartile range), or means \pm standard deviation. The distribution of continuous variables was examined by one-sample Kolmogorov-Smirnov test. We used the chi-square test or the Fisher's exact test for comparing categorical variables and the Mann-Whitney $U$ test or Student's $t$-test for comparing continuous variables. All statistical data were analyzed using the SPSS software version 18.0 (SPSS Inc., Chicago, IL, USA), with $\mathrm{p}<0.05$ indicating statistical significance.

\section{Results \\ Demographic characteristics of the study population}

Figure 1 illustrates the study's patient enrollment flow. We identified 3783 patients with a record of positive anti$\mathrm{HCV}$ antibody test from the hospital laboratory system. However, 1446 of them had a documentation of negative HCV RNA or SVR from anti-HCV therapy, thereby excluded from the analysis. Ultimately, we analyzed the remaining 2337 patients; their demographic characteristics are summarized in Table 1 . Most of the patients aged 60-80 years (Fig. 2). Patients who were younger $(<60)$, were male, and recently visited the gastroenterology division or internal medicine department as an outpatient had a higher success rate of callback. Conversely, patients who underwent clinic visits in departments other than the surgery or internal medicine department or aged $>80$ years had a lower callback success rate. Of the 1472 (42.2\%) patients tested for HCV RNA, 621 were positive.

\section{Results of different retrieval strategies}

Table 2 summarizes the results of different retrieval strategies. As found in the initial chart review and the treatment records in the PharmaCloud, most of the patients did not undergo anti-HCV therapy because of either 


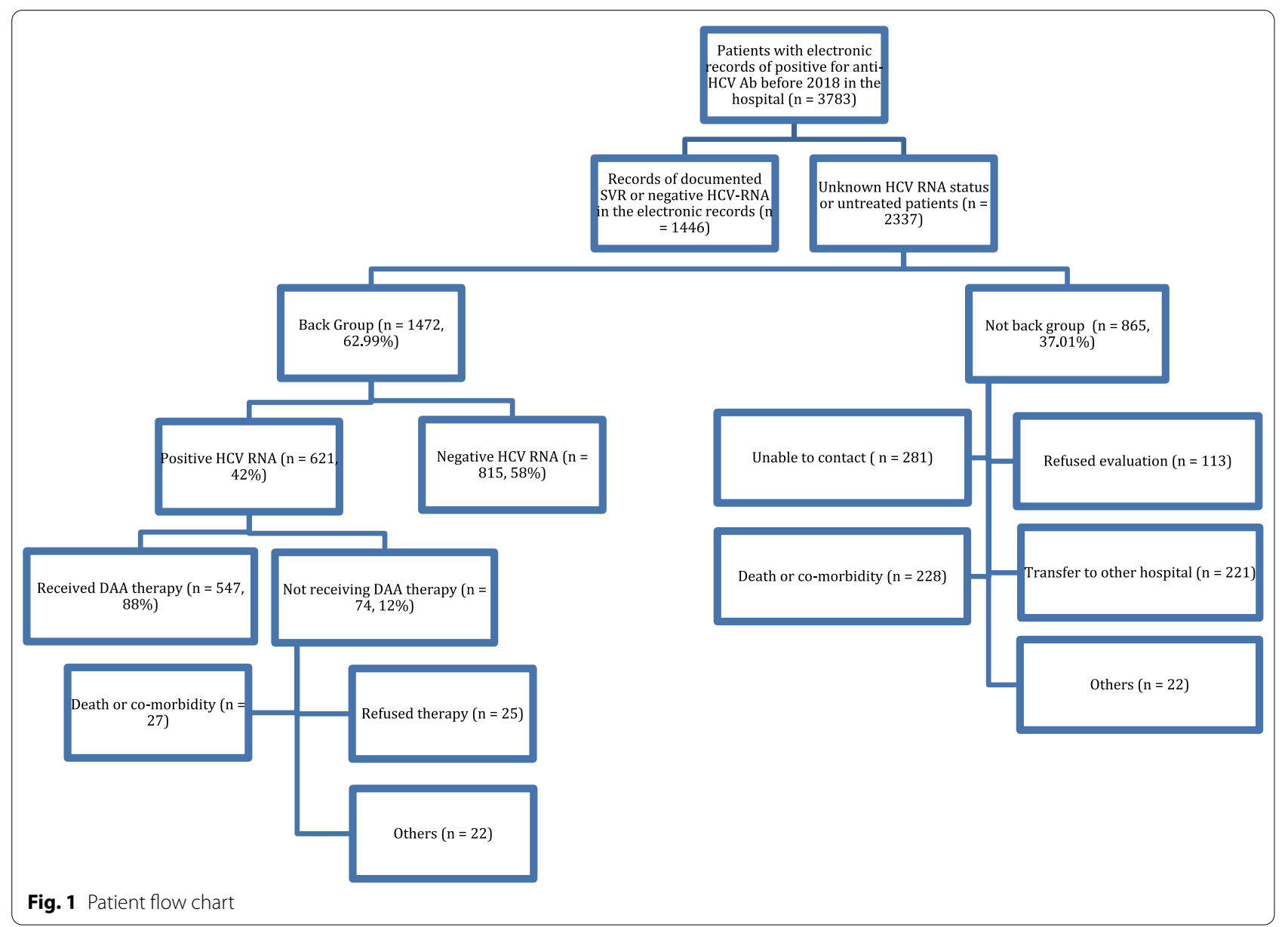

Table 1 Comparison of characteristics of patients with successful or failed callback for HCV testing

\begin{tabular}{|c|c|c|c|c|}
\hline & ALL patients $(n=2337)$ & Back $(n=1472)$ & Not Back $(n=865)$ & $p$ value \\
\hline Age, year, median (IQR) & $65(55-75)$ & $64(54-73)$ & $67(57-78)$ & $<0.001$ \\
\hline Age level, n/N (\%) & & & & $<0.001$ \\
\hline$<60$ & $794 / 2337(34.0)$ & $541 / 1472(36.8)$ & 253/865 (29.2) & $<0.001$ \\
\hline $60-80$ & 1154/2337 (49.4) & 738/1472 (50.1) & $416 / 865(48.1)$ & 0.362 \\
\hline$\geq 80$ & $389 / 2337(16.6)$ & 193/1472 (13.1) & 196/865 (22.7) & $<0.001$ \\
\hline Gender (M), n/N (\%) & $1151 / 2337(49.3)$ & 762/1472 (51.8) & $389 / 865(45.0)$ & 0.002 \\
\hline Residence, n/N (\%) & & & & 0.282 \\
\hline Changhua County & 1433/2337 (61.3) & $910 / 1472(61.8)$ & $523 / 865(60.5)$ & \\
\hline Changhua City & 464/2337 (19.9) & 299/1472 (20.3) & 165/865 (19.1) & \\
\hline Others & $440 / 2337(18.8)$ & 263/1472 (17.9) & $177 / 865(20.5)$ & \\
\hline Outpatient clinic/N (\%) & & & & $<0.001$ \\
\hline Division of Gastroenterology & $374 / 2337(16.0)$ & 293/1472 (19.9) & $81 / 865(9.4)$ & $<0.001$ \\
\hline Department of Internal Medicine & $668 / 2337(28.6)$ & $462 / 1472(31.4)$ & 206/865 (23.8) & $<0.001$ \\
\hline Department of Surgery & $536 / 2337(22.9)$ & $321 / 1472(21.8)$ & 215/865 (24.9) & 0.101 \\
\hline Other department in the hospital & 499/2337 (21.4) & 236/1472 (16.0) & 263/865 (30.4) & $<0.001$ \\
\hline Referral or unknown & $260 / 2337(11.1)$ & $160 / 1472(10.9)$ & 100/865 (11.6) & 0.656 \\
\hline
\end{tabular}




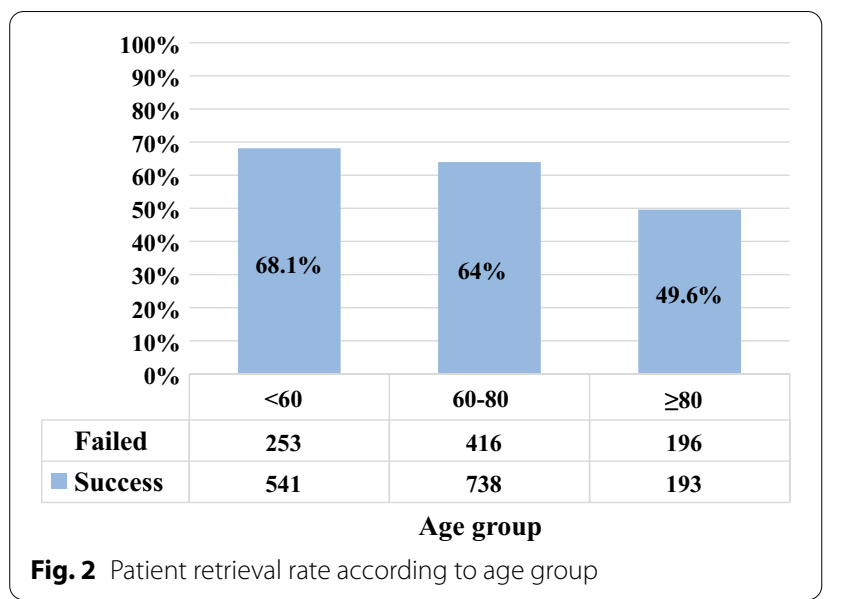

death or severe comorbidity. The remaining patients were approached by the electronic reminding system during their clinic visit, followed by telephone contact.

\section{Demographic characteristics of patients receiving the HCV RNA testing}

Table 3 lists the demographic characteristics of the 1472 patients with HCV RNA testing. Most of them aged 60-80 years old. Patients who were older $(\geq 80)$, were male, and had recent outpatient visit in a non-gastroenterology division had a high rate of positive HCV RNA testing. Subsequent anti-HCV therapy was initiated for $88.1 \%$ of patients who were tested positive for $\mathrm{HCV}$ RNA. The reasons for not initiating anti-HCV therapy in the hospital were as follows: patient refusal, severe comorbidity, therapy in other hospitals, and loss of subsequent patient contact.

\section{Discussion}

This single-center retrospective study reported the HCV microelimination results focusing on retrieving patients with $\mathrm{HCV}$ infection who were lost to follow-up in a hospital-based setting. Unfortunately, a significant proportion $(61.78 \%)$ of patients who were positive for $\mathrm{HCV}$ antibody was not evaluated for HCV therapy in the hospital. Through the project, a patient retrieval rate of $62.99 \%$ and the subsequent $\mathrm{HCV}$ treatment rate of $88 \%$ were achieved.

Screen All and Treat All strategy is ideal $[15,16]$ but not cost effective to eliminate HCV in most clinical settings. In the United States, only $20 \%$ of the 3.5 million $\mathrm{HCV}$-infected patients were screened by serological tests, with only $27 \%$ of them had HCV RNA testing, and finally, only $9 \%$ of the total pool was successfully treated [17]. Another study from the Swedish National Patient Register found that two-thirds of the 29,217 HCV-infected patients need further $\mathrm{HCV}$ care. Effective identification of patients with chronic $\mathrm{HCV}$ infection is the first step toward HCV elimination and is beneficial for clinicians and public health officials with limited financial support and lack of screening manpower. Screening for high-risk subpopulations, such as injection drug users [7], prisoners [8], HIV-infected patients [2, 9], or dialysis patients [3], has been effective as the first step toward HCV elimination. Before the instruction of current direct oral antiviral therapy, a low cure rate of $60 \%-80 \%$ and significant side effects from treatment related factor may account for the low HCV evaluation rate [18]. Patient factors such as unawareness of the disease, and lack of access to medical care, and healthcare system factors such lack of knowledge of the healthcare professionals and/or lack of interest for referral [19] account for the high percentage of $\mathrm{HCV}$-infected patients without referral for further confirmatory testing or treatment in the hospital.

One way to help eliminate $\mathrm{HCV}$ infection is by utilizing an electronic reminding system, which reportedly can increase the referral rate from 17 to $65 \%$ of patients for their subsequent therapy $[10,14,19]$. Considering that our study had already identified the HCV population, our hospital conducted the project "Retrieval of Lost Patients

Table 2 Patient retrieval strategies and results

\begin{tabular}{|c|c|c|c|c|c|}
\hline Patient retrieval methods & Telephone & Electronic Remind & SMS & Others $^{\mathrm{a}}$ & $p$ value \\
\hline Back group & 98 & 1349 & 7 & 18 & $p<0.0001$ \\
\hline Not back group & 515 & 90 & 3 & 277 & \\
\hline Treated in other hospital & 142 & 30 & & 49 & \\
\hline Unable to contact & 261 & 1 & 2 & 17 & \\
\hline Refused evaluation & 80 & 23 & 1 & 9 & \\
\hline Deceased & 9 & 1 & & 45 & \\
\hline Co-morbidity & 8 & 12 & & 153 & \\
\hline Others & 15 & 3 & & 4 & \\
\hline Total case number & 613 & 1419 & 10 & 295 & \\
\hline
\end{tabular}

${ }^{a}$ Other methods of patient retrieval include initial chart review for patient comorbidity status, survival and PharmaCloud review for therapy outside the hospital 
Table 3 Comparison of characteristics of patients receiving HCV RNA testing

\begin{tabular}{|c|c|c|c|c|}
\hline & $\begin{array}{l}\text { All patient receiving HCV RNA } \\
\text { testing }(n=1472)\end{array}$ & $\begin{array}{l}\text { Positive HCV RNA } \\
(n=621)\end{array}$ & $\begin{array}{l}\text { Negative HCV RNA } \\
(\mathrm{n}=851)\end{array}$ & $\mathrm{p}$ value \\
\hline Age, year, median (IQR) & $64(54-73)$ & $64(54-75)$ & $64(55-72)$ & 0.711 \\
\hline Age level, n/N (\%) & & & & 0.012 \\
\hline$<60$ & $541 / 1472(36.8)$ & $231 / 621(37.2)$ & $310 / 851(36.4)$ & 0.804 \\
\hline $60-80$ & 738/1472 (50.1) & 291/621 (46.9) & $447 / 851(52.5)$ & 0.036 \\
\hline$\geq 80$ & 193/1472 (13.1) & 99/621 (15.9) & $94 / 851(11.0)$ & 0.008 \\
\hline Gender, n/N (\%) & $762 / 1472(51.8)$ & $331 / 621(53.3)$ & $431 / 851(50.6)$ & 0.314 \\
\hline Residence, n/N (\%) & & & & 0.382 \\
\hline Others & 263/1472 (17.9) & $101 / 621(16.3)$ & 162/851 (19.0) & \\
\hline Changhua County & $910 / 1472(61.8)$ & $393 / 621(63.3)$ & $517 / 851(60.8)$ & \\
\hline Changhua City & 299/1472 (20.3) & $127 / 621(20.5)$ & 172/851 (20.2) & \\
\hline Outpatient clinic, n/N (\%) & & & & $<0.001$ \\
\hline Division of Gastroenterology & 293/1472 (19.9) & $104 / 621(16.7)$ & 189/851 (22.2) & 0.012 \\
\hline Department of internal medicine & 462/1472 (31.4) & 185/621 (29.8) & $277 / 851(32.5)$ & 0.285 \\
\hline Department of surgery & $321 / 1472(21.8)$ & $121 / 621(19.5)$ & 200/851 (23.5) & 0.075 \\
\hline Referral or unknown & 160/1472 (10.9) & $121 / 621(19.5)$ & 39/851 (4.6) & $<0.001$ \\
\hline Other department in the hospital & 236/1472 (16.0) & $90 / 621(14.5)$ & $146 / 851(17.2)$ & 0.192 \\
\hline Anti-HCV therapy provided, $\mathrm{n} / \mathrm{N}(\%)$ & $547 / 1472(88.1)$ & $547 / 621(88.1)$ & & \\
\hline Reason for not initiating anti-HCV therapy/N (\%) & & $74 / 621(11.9)$ & & \\
\hline Loss for contact & & $6 / 74(8.1)$ & & \\
\hline Treated in other hospital & & $7 / 74(9.5)$ & & \\
\hline Refusal of therapy & & 25/74 (33.8) & & \\
\hline Deceased & & $3 / 74(4.1)$ & & \\
\hline Severe illness & & $24 / 74(32.4)$ & & \\
\hline Others & & 9/74 (12.2) & & \\
\hline
\end{tabular}

of the Hospital," which aimed to eliminate hepatitis C infection in the hospital as an initial step toward $\mathrm{HCV}$ elimination. Our study found that $61.78 \%$ of the hospital patients were uninvestigated for HCV care; nonetheless, two-thirds of them can be reached using an electronic reminding system, and more patients were retrieved via telephone call.

A similar patient retrieval approach was reported in the Netherlands and Spain (Table 4). Beekmans et al. [20] reported that $30.1 \%$ of patients with hepatitis $C$ were lost to follow-up for hospital care and only three of the
150 candidate patients were re-evaluated for treatment in 2018. Furthermore, Patricia et al. [21] conducted the REACH study to retrieve patients with positive HCV diagnostic test results from four hospitals in Utrecht in 2019 , and they obtained a patient retrieval rate of $17.4 \%$. A recent interventional study from Spain [22] retrieved patients who were lost to follow-up through several phone calls and emails, and the retrieval rate was $46 \%$.

In our study, the patient retrieval rate was high, owing to the use of both in-hospital "passive" approach (i.e., physicians are systematic made aware through diverse

Table 4 List of studies focusing on the retrieval of lost-to-follow-up patients for HCV micro-elimination in the literature

\begin{tabular}{|c|c|c|c|c|c|c|}
\hline Year & Country & $\begin{array}{l}\text { Candidate for retrieval/ } \\
\mathrm{HCV} \mathrm{Ab}(+) \text { patient }\end{array}$ & $\begin{array}{l}\text { Retrieved patient/ } \\
\text { candidate for retrieval }\end{array}$ & $\begin{array}{l}\text { Positive HCV RNA/ } \\
\text { tested patient }\end{array}$ & $\begin{array}{l}\text { HCV therapy/ } \\
\text { positive HCV RNA }\end{array}$ & References \\
\hline 018 & Holland & 150/499 (30.1\%) & $4 / 20(25 \%)$ & $3 / 4(75 \%)$ & 3/3 (100\%) & Beekmans et al. [20] \\
\hline 2019 & Netherland & $269 / 1913(14.1 \%)$ & $47 / 269$ (17.4\%) & $42 / 47(89.4 \%)$ & $42 / 42(100 \%)$ & Kracht et al. [21] \\
\hline 2020 & Netherland & $308 / 689$ (44.7\%) & $90 / 308$ (29\%) & 19/34 (55.9\%) & $12 / 19(61.2 \%)$ & Heil et al. [27] \\
\hline 2021 & Spain & $530 / 1330(39.8 \%)$ & $244 / 530(46 \%)$ & $153 / 244(62.7 \%)$ & $141 / 153(92.2 \%)$ & Guerra Veloz et al. [22] \\
\hline 2021 & Taiwan & $2337 / 3783$ (61.8\%) & $1472 / 2337$ (62.9\%) & $621 / 1472(42.2 \%)$ & $547 / 621(88.1 \%)$ & Present study \\
\hline
\end{tabular}


electronic reminding systems and reflex anti-HCV testing) and out-hospital "active" approach (i.e., contacting patients directly by phone and arranging schedules for one-step HCV testing to increase the test uptake). Hence, a combined approach is required to maximize the retrieval rate of patients who were lost to followup, especially when COVID-19 has significant impact for patient retrieval in the health care system during 2020 [23, 24]. In addition, multiple education activities for patients or health professionals from the government part and hospital part during the period explains our high patient retrieval rate. As reported in a previous study, older patients and patients with clinic visit in other departments are more difficult to retrieve [20, $22,25]$, and further interventional measurements, such as education for both patients and health professionals, may further increase the patient retrieval rate and contribute to the goal of $\mathrm{HCV}$ elimination.

Meanwhile, the current study has several limitations. First, this retrospective study enrolled patients over a 1-year period in a single institution, with no standardized protocol to record the patients' baseline characteristics for further analysis to enhance patient acceptance. Second, we encouraged patients during telephone call to undergo HCV testing and treatment. We failed to thoroughly investigate the reasons for patient refusal during telephone call; possible reasons include unstable housing or financial resources, concomitant psychiatric disease, or concern for COVID-19 infection in the hospital [26].

\section{Conclusions}

This HCV-targeted callback approach identified a significant proportion of patients with positive $\mathrm{HCV}$ antibody that remained unevaluated for HCV RNA testing or therapy in the hospital. Therefore, this approach is feasible and effective in achieving $\mathrm{HCV}$ microelimination.

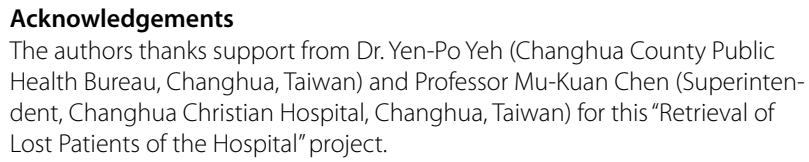
Health Bureau, Changhua, Taiwan) and Professor Mu-Kuan Chen (Superintendent, Changhua Christian Hospital, Changhua, Taiwan) for this "Retrieval of Lost Patients of the Hospital" project.

\section{Authors' contributions}

HHY: Draft of the manuscript; PYS, ILL, YHZ, YCH: Draft the manuscript and perform the study. SPH, PKH: Analysis the data and approve the manuscript. YYC: Draft and approve the manuscript.

\section{Funding}

The authors received funding from Changhua Christian Hospital (109-CCHIRP-008 and 108-CCH-IRP-018).

\section{Availability of data and materials}

The datasets used and/or analyzed during the current study are available from the corresponding author on reasonable request.

\section{Declarations}

\section{Ethics approval and consent to participate}

The study was approved by Changhua Christian Hospital Institutional Review Board (CCH IRB No. 200403) The need for patient consent to data extraction was waived by the institutional review board, because the study involved minimal risk.

\section{Consent for publication}

Not applicable.

\section{Competing interests}

None.

\section{Author details}

${ }^{1}$ Division of Gastroenterology, Department of Internal Medicine, Changhua Christian Hospital, No. 135 Nanhsiao Street, Changhua, Taiwan. ${ }^{2}$ General Education Center, Chienkuo Technology University, Changhua, Taiwan. ${ }^{3}$ Department of Electrical Engineering, Chung Yuan Christian University, Taoyuan, Taiwan. ${ }^{4}$ Department of Hospitality Management, MingDao University, Changhua, Taiwan.

Received: 26 February 2021 Accepted: 23 April 2021

Published online: 08 May 2021

\section{References}

1. Chi CT, Chen CY, Su CW, Chen PY, Chu CJ, Lan KH, Lee IC, Hou MC, Huang YH. Direct-acting antivirals for patients with chronic hepatitis $\mathrm{C}$ and hepatocellular carcinoma in Taiwan. J Microbiol Immunol Infect. 2019;14;S1684-1182(19)30157-4.

2. Liu I-L, Liu T, Zeng Y-H, Huang S-P, Hsu Y-C, Su P-Y, Yen H-H. Interferon-free anti-HCV therapy has a better treatment response rate and adherence than interferon-based therapy for patients with HCV/HIV coinfection: a single-center retrospective study. Changhua J Med. 2020;18(4):122-9.

3. Yen HH, Su PY, Zeng YH, Liu IL, Huang SP, Hsu YC, Chen YY, Yang CW, Wu SS, Chou KC. Glecaprevir-pibrentasvir for chronic hepatitis C: comparing treatment effect in patients with and without end-stage renal disease in a real-world setting. PLoS ONE. 2020;15(8):e0237582.

4. Yen HH, Shih KL, Lin TT, Su WW, Soon MS, Liu CS. Decreased mitochondrial deoxyribonucleic acid and increased oxidative damage in chronic hepatitis C. World J Gastroenterol. 2012;18(36):5084-9.

5. Hasan F, Alfadhli A, Al-Gharabally A, Alkhaldi M, Colombo M, Lazarus JV. Accelerating the elimination of hepatitis $C$ in Kuwait: an expert opinion. World J Gastroenterol. 2020;26(30):4415-27.

6. Hatzakis A, Lazarus JV, Cholongitas E, Baptista-Leite R, Boucher C, Busoi CS, Deuffic-Burban S, Chhatwal J, Esmat G, Hutchinson S, et al. Securing sustainable funding for viral hepatitis elimination plans. Liver Int. 2020;40(2):260-70.

7. Perez Castano Y, Chouza Perez JM, Sanz Largo V, Almandoz Cortajarena E, Gomez Garcia A, Esandi Gonzalez FJ, Castiella Eguzkiza A, Arranz Diaz S, Urtasun Lugea I, Sanchez Iturri MJ, et al. Linkage to care strategy for the micro-elimination of hepatitis $C$ among parenteral drug users on methadone replacement therapy in Gipuzkoa. Rev Esp Enferm Dig. 2020;112(7):545-9.

8. Cuadrado A, Cobo C, Mateo M, Blasco AJ, Cabezas J, Llerena S, Fortea Jl, Lazaro P, Crespo J. Telemedicine efficiently improves access to hepatitis C management to achieve HCV elimination in the penitentiary setting. Int J Drug Policy. 2020;88:103031.

9. Li CW, Yang CJ, Sun HY, Tsai MS, Lin SP, Lin TY, Cheng CY, Lee YC, Huang YS, Liu CE, et al. Changing seroprevalence of hepatitis C virus infection among HIV-positive patients in Taiwan. PLoS ONE. 2018;13(3):e0194149.

10. Fujii H, Yamaguchi S, Kurai O, Miyano M, Ueda W, Oba H, Aoki T, Enomoto M, Kawada N, Okawa K. Putting "sticky notes" on the electronic medical record to promote intra-hospital referral of hepatitis B and C virus-positive patients to hepatology specialists: an exploratory study. BMC Infect Dis. 2016;16:410.

11. Tokushima Y, Tago M, Tokushima M, Katsuki NE, Iwane S, Eguchi Y, Yamashita SI. Management of hepatitis B surface antigen and hepatitis C 
antibody-positive patients by departments not specializing in hepatology at a suburban university hospital in Japan: a single-center observational study. Int J Gen Med. 2020;13:743-50.

12. Wu GH, Pwu RF, Chen SC. Achieving hepatitis C elimination in Taiwanovercoming barriers by setting feasible strategies. J Formos Med Assoc. 2018;117(12):1044-5.

13. Liao CY, Wu MF, Poon SK, Liu YM, Chen HC, Wu CL, Sheu WH, Liou WS. Improving medication safety by cloud technology: progression and value-added applications in Taiwan. Int J Med Inform. 2019:126:65-71.

14. Huang CF, Wu PF, Yeh ML, Huang Cl, Liang PC, Hsu CT, Hsu PY, Liu HY, Huang YC, Lin ZY, et al. Scaling up the in-hospital hepatitis C virus care cascade in Taiwan. Clin Mol Hepatol. 2021;27(1):136-43.

15. Liu L, Xu H, Hu Y, Shang J, Jiang J, Yu L, Zhao C, Zhang D, Zhang X, Li J, et al. Hepatitis $\mathrm{C}$ screening in hospitals: find the missing patients. Virol $J$. 2019;16(1):47

16. Md Said R, Mohd Zain R, Chan HK, Soelar SA, Rusli N, Nasir NH, Zakaria R, Hassan MRA. Find the Missing Millions: Malaysia's experience with nationwide hepatitis $\mathrm{C}$ screening campaign in the general population. $J$ Viral Hepat. 2020;27(6):638-43.

17. Dhiman RK, Premkumar M. Hepatitis C virus elimination by 2030: conquering mount improbable. Clin Liver Dis (Hoboken). 2020;16(6):254-61.

18. Yen HH, Su PY, Liu IL, Zeng YY, Huang SP, Hsu YC, Yang CW, Chen YY. Direct-acting antiviral treatment for Hepatitis C Virus in geriatric patients: a real-world retrospective comparison between early and late elderly patients. PeerJ. 2021;9:e10944.

19. Hidaka I, Enomoto M, Sato S, Suetsugu A, Matono T, Ito K, Ogawa $K$, Inoue J, Horino M, Kondo Y, et al. Establishing efficient systems through electronic medical records to promote intra-hospital referrals of hepatitis virus carriers to hepatology specialists: a multicenter questionnaire-based survey of 1,281 healthcare professionals. Intern Med. 2021;60(3):337-43.

20. Beekmans N, Klemt-Kropp M. Re-evaluation of chronic hepatitis B and hepatitis C patients lost to follow-up: results of the Northern Holland hepatitis retrieval project. Hepatol Med Policy. 2018;3:5.
21. Kracht PAM, Arends JE, van Erpecum KJ, Thijsen SFT, Vlaminckx BJM, Weersink AJL, Wensing AMJ, Deege MPH, Dimmendaal M, Stadhouders $P$, et al. REtrieval and cure of chronic hepatitis C (REACH): results of microelimination in the Utrecht province. Liver Int. 2019;39(3):455-62.

22. Guerra Veloz MF, Pino Bellido P, Cordero Ruiz P, Vega Rodriquez F, Bellido Munoz F, Ramirez de Arellano E, Caunedo Alvarez A, Pascual Hernandez A, Carmona Soria I. HCV micro-elimination strategies: an interventional study in diagnosed patients without access to the system. Liver Int. 2021:41(5):928-33.

23. Karimi-Sari H, Rezaee-Zavareh MS. COVID-19 and viral hepatitis elimination programs: are we stepping backward? Liver Int. 2020;40(8):2042.

24. Wong GL, Wong VW, Thompson A, Jia J, Hou J, Lesmana CRA, Susilo A, Tanaka Y, Chan WK, Gane E, et al. Management of patients with liver derangement during the COVID-19 pandemic: an Asia-Pacific position statement. Lancet Gastroenterol Hepatol. 2020;5(8):776-87.

25. Yehia BR, Schranz AJ, Umscheid CA, Lo Re V 3rd. The treatment cascade for chronic hepatitis $C$ virus infection in the United States: a systematic review and meta-analysis. PLoS ONE. 2014;9(7):e101554.

26. Kracht PAM, Arends JE, Hoepelman AIM, Vervoort S. The balancing perspective of hard-to-reach hepatitis C patients who were lost to follow-up: a qualitative study. PLoS ONE. 2020;15(4):e0230756.

27. Heil J, Soufidi K, Stals F, Frantzen H, Robroek-Schaecken A, Bakker CM, van Nunen AB, Dukers-Muijrers N, Hoebe C. Retrieval and re-evaluation of previously diagnosed chronic hepatitis $C$ infections lost to medical follow-up in the Netherlands. Eur J Gastroenterol Hepatol. 2020;32(7):851-6.

\section{Publisher's Note}

Springer Nature remains neutral with regard to jurisdictional claims in published maps and institutional affiliations.
Ready to submit your research? Choose BMC and benefit from:

- fast, convenient online submission

- thorough peer review by experienced researchers in your field

- rapid publication on acceptance

- support for research data, including large and complex data types

- gold Open Access which fosters wider collaboration and increased citations

- maximum visibility for your research: over $100 \mathrm{M}$ website views per year

At BMC, research is always in progress.

Learn more biomedcentral.com/submissions 